\title{
Effects of Ethanol Sustained Exposure on Human Trophoblast Cell Hormonal Production
}

\author{
Clave $\mathbf{S}^{1,2 \#}$, Joya $\mathbf{X}^{1,2 \#}$, Salat-Batlle $\mathrm{J}^{1,2}$, Martinez $\mathbf{S E}{ }^{1}$, Garcia-Algar $\mathbf{O}^{1,2,3 *}$ and Vall $\mathbf{O}^{1,2,3}$
}

${ }^{1}$ Unitat de Recerca Infància i Entorn (URIE), Institut Hospital del Mar d'Investigacions Mèdiques (IMIM), Barcelona, Spain

${ }^{2}$ Red de Salud Materno Infantil y del Desarrollo (SAMID), Programa RETIC, Instituto Carlos III, Madrid, Spain

${ }^{3}$ Department de Pediatria, Obstetricia i Ginecologia, i Medicina Preventiva, Universitat Autònoma de Barcelona (UAB), Bellaterra, Spain

\#Equal Contributors

\begin{abstract}
Foetal Alcohol Syndrome Disorder (FASD) is a complex condition resulting from the consumption of alcohol during pregnancy. Diagnosis of prenatal exposure to alcohol depends on questionnaire about consumption, biomarkers in neonatal alternative matrices as maternal hair and neonatal meconium, and postnatal clinical data as facial features. However, biomarkers of cellular damage due to exposure to alcohol during pregnancy are lacking. Prenatal alcohol exposure can lead to altered placental cellular function, resulting in changes in hormone production. Herein, the alteration in the synthesis of this hormonal output was studied using a cultured human trophoblast cell line (JEG3). The production of insulin-like grow factor 2 (IGF2), human chorionic gonadotrophin (hCG), human placental lactogen (hPL) and pregnancy specific glycoprotein 1 (PSG1) was analyzed. Sustained ethanol exposure significantly increased the cellular production and release of IGF2 and hCG in a dose-dependent manner related to the ethanol input. Moreover, ethanol exposure also caused a loss in cell viability and a significant decrease in total protein production. This hormonal alteration may be used in future studies as preliminary candidate to validate surrogate biomarkers of damage.
\end{abstract}

Keywords: Alcohol; Trophoblast cell; IGF2; hCG; Biomarkers of damage; Ethanol

\section{Introduction}

Chronic alcohol consumption can cause damage to various organs, resulting in different disturbances [1]. One of the health consequences of alcohol consumption in pregnant women is Foetal Alcohol Syndrome (FAS), a condition resulting from the exposure of the developing embryo to ethanol $[2,3]$. The clinical features of FAS can be broadly divided into: morphological malformations, especially craniofacial defects, central nervous system impairment, neuropsychological traits, and growth retardation [4,5]. Offspring of mothers who drink heavily during pregnancy can develop FAS with all the symptoms described above, but some cases show no physical or morphological evidences of prenatal alcohol effects at birth [6]. On the other hand, current estimates suggest that at least $9.1 / 1000$ of the paediatric population has Foetal Alcohol Syndrome Disorder (FASD). A large majority of this group is characterized by adverse neurobehavioral consequences that may be misdiagnosed for years, diminishing the beneficial prospect of earlier interventional opportunities [7,8].

Neonatal FAS can be properly diagnosed based on its facial features, but for the majority of FASD cases, strategies for diagnosis are lacking. The detection of these newborns and children has been focused in questionnaire about consumption and biomarkers of exposure as direct ethanol, ethanol metabolites or compounds that chemically interact with ethanol in neonatal alternative matrices [9].

Up to date, the determination of Fatty Acid Ethyl Esters (FAEEs) in meconium or maternal hair is the best procedure to identify exposed newborns, but with a cut off value in the range of heavy drinking population. In addition, there are not biomarkers that offer reliable information about the injury in the foetus [10]. In this sense, only a few number of papers have proposed potential biomarkers of damage associated to prenatal ethanol exposure $[11,12]$.

Placenta is the most accessible foetal-maternal tissue after birth and provides valuable information about the course of pregnancy
[13]. As known previously, placental function can be altered by ethanol exposure, resulting in an increased risk for a wide range of adverse pregnancy outcomes [14]. For these reasons, placenta could be considered a target tissue to find biomarkers of damage.

Herein, as a preliminary in vitro study, we used JEG3 trophoblast cell line which is specifically present in the syncytiotrophoblast and is the major hormone-producing cell line, expressing a high number of hormones and growth factors $[15,16]$. Of all these, insulin-like grow factor 2 (IGF2), human chorionic gonadotrophin (hCG), human placental lactogen (hPL) and pregnancy specific glycoprotein 1 (PSG1) are the most relevant based on previous published research [17-19].

So, the main objective of this study was to evaluate the effect of sustained ethanol exposure on the hormonal production of JEG3 cultured trophoblasts to propose preliminary surrogate biomarkers of damage.

\section{Materials and Methods}

\section{Cell culture}

Human placental choriocarcinoma cell line $[20,21]$ was purchased from the American Type Culture Collection (ATCC): JEG3 (HTB-36, Manassas, USA). Cells were maintained in Minimum Essential Media

*Corresponding author: Oscar Garcia Algar, Unitat de Recerca Infància i Entorn (URIE), Institut Hospital del Mar d'Investigacions Mèdiques (IMIM) - Parc de Salut Mar, Parc de Recerca Biomèdica de Barcelona (PRBB), C/ Dr. Aiguader, 88 - 08003 - Barcelona, Spain, Tel: 0034 933160454; E-mail: 90458@parcdesalutmar.cat

Received November 21, 2013; Accepted December 23, 2013; Published January 02, 2014

Citation: Clave S, Joya X, Salat-Batlle J, Martinez SE, Garcia-Algar O, et al. (2014) Effects of Ethanol Sustained Exposure on Human Trophoblast Cell Hormonal Production. J Steroids Horm Sci 5: 121. doi:10.4172/2157-7536.1000121

Copyright: () 2014 Clave S, et al. This is an open-access article distributed under the terms of the Creative Commons Attribution License, which permits unrestricted use, distribution, and reproduction in any medium, provided the original author and source are credited. 
Citation: Clave S, Joya X, Salat-Batlle J, Martinez SE, Garcia-Algar O, et al. (2014) Effects of Ethanol Sustained Exposure on Human Trophoblast Cell Hormonal Production. J Steroids Horm Sci 5: 121. doi:10.4172/2157-7536.1000121

Page 2 of 5

(MEM) supplemented with 10\% ( $v / v)$ Foetal Bovine Serum (FBS), 20 $\mathrm{mM}$ L-glutamine, $10 \mathrm{mM}$ sodium pyruvate, $100 \mathrm{mg} / \mathrm{mL}$ streptomycin and $100 \mathrm{U} / \mathrm{mL}$ penicillin; all get from Gibco, Montreal, CA. Cell cultures were maintained at $37^{\circ} \mathrm{C}$ in humidified $5 \% \mathrm{CO}_{2}$ atmosphere.

\section{Experimental design}

Similarly to previous studies [17,22], a comparison between placental cells non-exposed and exposed to standard concentrations of ethanol was done. It was decided to expose every $72 \mathrm{~h}$ two groups of cells at concentrations of $25 \mathrm{mM}$ and $50 \mathrm{mM}$ ethanol (VWR, Radnor, USA). These concentrations are equivalent to the expected in the human placental tissue from moderate ethanol consumers $(5-90 \mathrm{mg} /$ $\mathrm{dL}$; approximately $20 \mathrm{mM}$ ) [23] and in alcohol-depending consumers (386 mg/dL; approximately $85 \mathrm{mM}$ ) [24]. To prevent evaporation of ethanol during this incubation period, we used culture dishes wrapped in parafilm [25]. This system almost completely stabilized the ethanol concentration in the culture medium for 3 days with an acceptable loss of $20 \%$ of ethanol [25-27]. Control cells were cultured in the same conditions in the absence of ethanol. These three groups were grown in separated flasks during all the sustained exposure. Every five passages we obtained three subculture replicates of each group to carry out the experiments, at a seeding density of $0.1 \times 10^{6}$ viable cells $/ \mathrm{mL}$ in $100 \mathrm{~mm}$ plate (Corning Life Sciences, Amsterdam, The Netherlands). Cells and culture medium of these replicates were harvested after $1 \mathrm{~h}, 24 \mathrm{~h}$ and 72 $\mathrm{h}$ of the last ethanol exposure [28,29] (Figure 1).

\section{Western blotting}

Cell extracts were prepared from $100 \mathrm{~mm}$-plate cell culture by adding $100 \mu \mathrm{L}$ of cold lysis buffer ( $50 \mathrm{mM}$ Tris- $\mathrm{HCl}, 150 \mathrm{mM} \mathrm{NaCl}, 2$ mM EDTA, $50 \mathrm{mM} \mathrm{NaF}, \mathrm{pH}$ 7.4) containing protein and phosphatase inhibitors; all purchased from Sigma-Aldrich, St. Louis, USA. Samples were maintained 10min on ice and centrifuged at 12000rpm. Protein level was determined with DC Protein Assay (Bio-Rad, Hercules, USA). Protein lysates $(50 \mu \mathrm{g})$ were run in a SDS/PAGE and transferred (90 $\mathrm{min}, 100 \mathrm{mV}$ ) to nitrocellulose membranes (Whatman, Kent, UK). Membranes were blocked with $4 \%$ dehydrated milk and blotted with the indicated primary antibodies $\mathrm{O} / \mathrm{N}$ at $4^{\circ} \mathrm{C}$ (Table 1 ). Membranes were washed in TBS-Tween and incubated for $60 \mathrm{~min}$ with a goat anti-mouse IgG-HRP (1:10000) (Santa Cruz Biotech; sc-2005) washed with TBS-Tween and developed with Pierce ECL Western Blotting Substrate (Thermo Fisher Scientific, Rockford, USA) according to manufacturer's instructions. To quantify, ImageJ software (National Institute of Health, USA) was used. The values of $25 \mathrm{mM}$ and $50 \mathrm{mM}$ groups were normalized against the control group.

\section{ELISA assays}

Cell medium of every $100 \mathrm{~mm}$-plate were recovered and centrifuged at $1200 \mathrm{rpm}$. These mediums were used as samples for ELISA kits for testing IGF2 and hCG (Biovendor, Modrice, Czech Republic). The procedure was carried out according to manufacturer's instructions. Measurement of absorbance was done at the established wavelength of $450 \mathrm{~nm}$ (Infinite M200, Tecan Group Ltd., Männedorf, Switzerland), Results were plotted with the standard curve and normalized by the number of viable cells counted at the moment of harvesting.

\section{Viability assays}

To extrapolate the ELISA results in relation to the number of cells alive, cell viability was determined at the moment of harvesting 100 mm-plates of the three lineages using trypan blue/haemocytometer

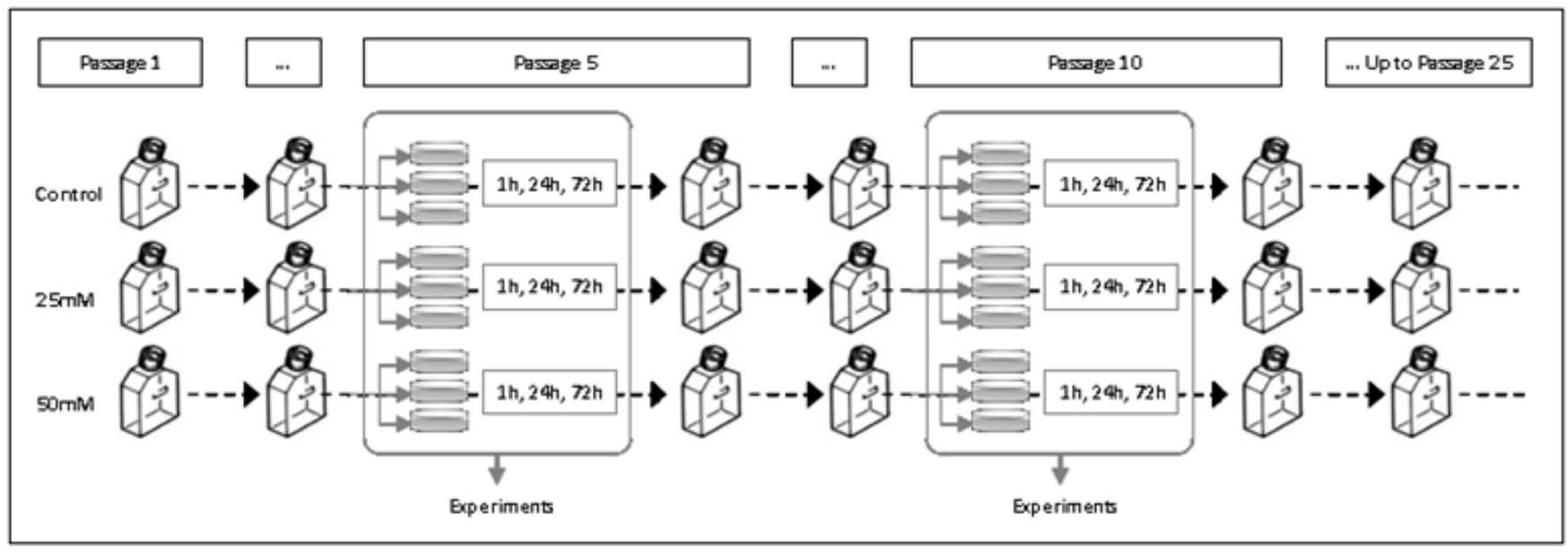

Figure 1: Experimental design: Control, $25 \mathrm{mM}$ and $50 \mathrm{mM}$ groups were groups were grown separated flasks during all the sustained exposure. Every five passages we obtained three subculture replicates of each group to carry out the experiments, at a seeding density of $0.1 \times 10^{6}$ viable cells $/ \mathrm{ml}$ in $100 \mathrm{~mm}$ - plate. Cells and culture medium of these replicates were harvested after $1 \mathrm{~h}, 24 \mathrm{~h}$ and $72 \mathrm{~h}$ of the last ethanol exposure.

\begin{tabular}{|c|c|c|c|c|}
\hline Target & Source & Species & Size(kDa) & Dilution \\
\hline IGF2 & Santa Cruz Biotech.; sc-74119 & Mouse & 23 & $1: 1000$ \\
\hline hCG & R\&D Systems; MAB4169 & Mouse & 28 & $1: 2000$ \\
\hline $\mathrm{hPL}$ & Abcam; EPR8264 & Rabbit & 25 & $1: 3000$ \\
\hline PSG1 & Abcam; ab114940 & Mouse & 69 & $1: 1000$ \\
\hline B-Actin & Sigma-Aldrich; A3859 & Mouse & 42 & $1: 10000$ \\
\hline
\end{tabular}

Table 1: Antibodies used for Western blot detection. 
Citation: Clave S, Joya X, Salat-Batlle J, Martinez SE, Garcia-Algar O, et al. (2014) Effects of Ethanol Sustained Exposure on Human Trophoblast Cell Hormonal Production. J Steroids Horm Sci 5: 121. doi:10.4172/2157-7536.1000121

Page 3 of 5

exclusion method. Moreover, protein levels were determined with DC Protein Assay.

\section{Statistical analysis}

Statistical analysis was performed using the one-way analysis of variance (ANOVA) or Student's t-test (GraphPad Software, San Diego, CA, USA). Results are expressed as the mean \pm standard deviation of five biological replicates. A $p$ value less than 0.005 was considered statistically significant.

\section{Results}

\section{Effects of ethanol exposure in JEG3 cells IGF2 production}

Alcohol treated trophoblast cells showed an important increase in the expression of IGF2 (Figure 2). The $25 \mathrm{mM}$ and $50 \mathrm{mM}$ groups showed stronger bands in Western blot analyses when compared with the control group (Figure 2A). Quantified bands showed an increasing trend in IGF2 release depending in the exposure time and dosage (Figure 2B). To validate these results, an ELISA test was performed. ELISA results confirmed increased IGF2 release due to ethanol exposure in a dose depending manner (Figure 2C). The $25 \mathrm{mM}$ group showed significant increases in IGF2 values after $72 \mathrm{~h}$ exposure time ( $p<0.005$ vs. control). On the other hand, the $50 \mathrm{mM}$ group, showed significant increases values after $1 \mathrm{~h}, 24 \mathrm{~h}$ and $72 \mathrm{~h}$ exposure times $(p<0.005$ vs. control) (Figure 2D).

\section{Effects of ethanol exposure in JEG3 cells hCG production}

Trophoblast cells treated with ethanol showed an increase in the expression of hCG (Figure 3). The $25 \mathrm{mM}$ and $50 \mathrm{mM}$ groups showed stronger bands in Western blot analyses when we compared with the control group. This fact was more evident in $50 \mathrm{mM}$ group (Figures 3A and $3 \mathrm{~B}$ ). The $50 \mathrm{mM}$ group increased hCG release after $1 \mathrm{~h}, 24 \mathrm{~h}$ and $72 \mathrm{~h}$ exposure times ( $p<0.005$ vs. control) (Figures $3 B$ and $3 D$ ). In the ELISA test, $50 \mathrm{mM}$ group showed significant increases after all exposure times $(p<0.005$ vs. control) (Figures 3C and 3D).

\section{Effects of ethanol exposure in JEG3 cells hPL and PSG1 production}

Ethanol exposure did not change hPL and PSG1 levels significantly. In Western blot analyses, an increment of hPL was observed in each 25 $\mathrm{mM}$ group exposure times, but it decreased to the control group level when the cells were treated with $50 \mathrm{mM}$. PSG1 levels were lower in both exposed groups when compared with the control group, but these differences were not significant.

\section{Cell viability and protein levels in JEG3 culture cells}

Ethanol input decreased viability of JEG3 cell line resulting significant in $50 \mathrm{mM}$ group after $72 \mathrm{~h}$ exposure time $(p<0.005$ vs. control) (Figures $4 \mathrm{~A}$ and $4 \mathrm{C}$ ). Similar to the viable count, a reduction in total protein levels was observed. The $50 \mathrm{mM}$ group showed significant decreased levels ( $p<0.005$ vs. control) after $24 \mathrm{~h}$ and $72 \mathrm{~h}$ exposure times ( $p<0.005$ vs. control) (Figures $4 \mathrm{~B}$ and $4 \mathrm{C}$ ).

\section{Discussion}

The first finding of this in vitro study was the detection of a high expression of IGF2 in cell lysates by Western blot, in agreement with subsequent ELISA results, in a significant dose-dependent manner. This effect was observed when cells were exposed to increasing concentrations of ethanol. The IGF system activates PI3 kinase-Akt and it is related with prenatal and postnatal growth and this pathway is involved in processes such as growth, survival and metabolic signal transmission [30]. A reduced expression of placental IGF2 has been associated with intrauterine growth restriction [31]. Thus, it is likely that higher levels of IGF2 allow catch-up growth in children with FASD [18].

Previous studies, using rodents as an in vivo model, demonstrated that only continuous ethanol exposure induced an increase in placental igf2 mRNA levels [31]. The ethanol blood levels of these animals were approximately $50-60 \mathrm{mM}$ during all their pregnancy. These rodents blood ethanol concentration and those found in our cell culture supernatant are comparable at cellular level. Thus, our results showed that IGF2 levels increased similarly when cells were exposed during short periods $(1 \mathrm{~h})$ and long periods $(72 \mathrm{~h})$ of time. Therefore, the levels were also modified with occasional exposure to alcohol.

Recently, other authors observed increased IGF2 serum levels in children diagnosed with FAS [18]. This study only associated the increase in the expression of IGF2 to ethanol exposure but it does not

(A)

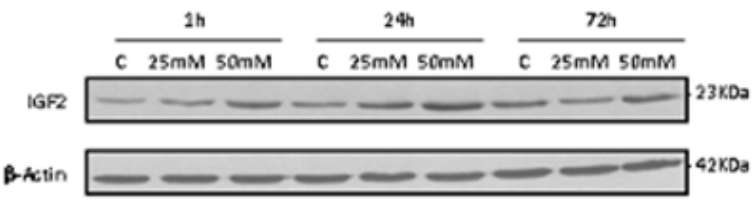

(B)

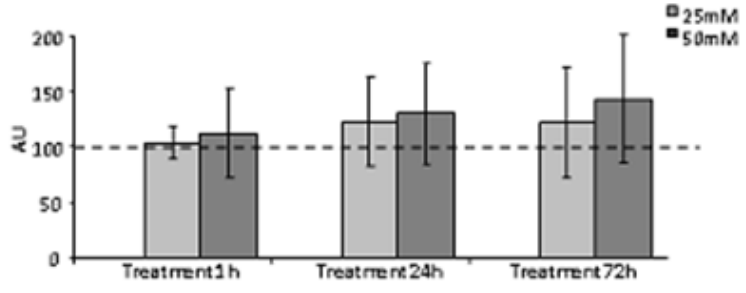

(C)

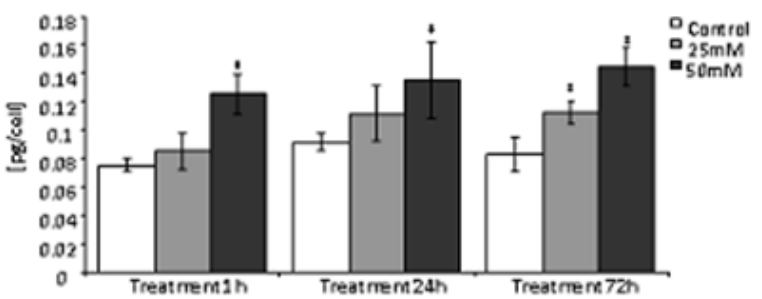

(D)

\begin{tabular}{|c|c|c|c|c|}
\hline \multicolumn{5}{|c|}{ ICRlenels } \\
\hline \multirow{4}{*}{$m(A)$} & & contrd & $2 \mathrm{~mm}$ & $5 \mathrm{amm}$ \\
\hline & th & 100 & $108 \Omega \pm 150$ & $11168+38, A 8$ \\
\hline & 2कh & 100 & $121.64 \pm 32.50$ & 128.7245 .16 \\
\hline & 7 क & 100 & 172521486 & $1404 \pm 5765$ \\
\hline \multirow{4}{*}{$\underset{(0 \mathrm{e} / \mathrm{w})}{\text { rusa }}$} & & contrd & $2 \mathrm{~mm}$ & $50 \mathrm{~mm}$ \\
\hline & ih & $0.073+0.005$ & $0065+0013$ & $0.130=0014^{b}$ \\
\hline & 2क & $0.091+0.006$ & 0.110:0013 & $0180=0.03^{\circ}$ \\
\hline & $72 h$ & $0.082+0.012$ & Q110A0DOE" & $0.150=0013^{\circ}$ \\
\hline
\end{tabular}

Figure 2: Effects of ethanol treatments in JEG3 cells IGF2 production. $\{A\}$ Representative Western blot detecting IGF2. $\{B\}$ Columns show the mean $\pm \mathrm{SD}$ of $25 \mathrm{mM}$ and $50 \mathrm{mM}$ groups normalized against the control group represented as a discontinuous line $\{100 \mathrm{AU}\}$. Results are expressed as arbitrary units $\{A U\}$. $\{C\}$ columns show the mean $\pm S D$ IGF2 content in JEG3 cells culture medium from the three groups measured by ELISA. Results are expressed as pg/cell. \{D\} Western blot and ELISA results for each group. " $p<0.005$ vs. control. 
Citation: Clave S, Joya X, Salat-Batlle J, Martinez SE, Garcia-Algar O, et al. (2014) Effects of Ethanol Sustained Exposure on Human Trophoblast Cell Hormonal Production. J Steroids Horm Sci 5: 121. doi:10.4172/2157-7536.1000121

Page 4 of 5

(A)

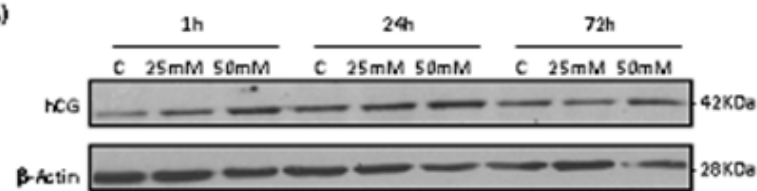

(B)

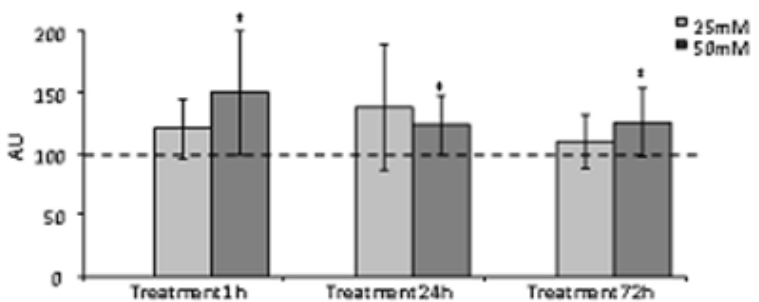

(C)

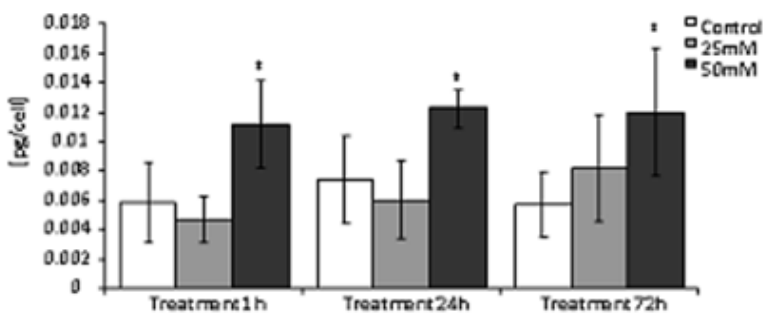

(D)

\begin{tabular}{|c|c|c|c|c|}
\hline \multicolumn{5}{|c|}{ haslowis } \\
\hline \multirow{4}{*}{$m(a)$} & & Control & $25 \mathrm{mM}$ & $50 \mathrm{mM}$ \\
\hline & Ith & 10 & $2000+2420$ & $150.02 \pm 51.04^{\circ}$ \\
\hline & 24h & 100 & $137 S 9+51.57$ & $12335+2689^{*}$ \\
\hline & $7 \mathbf{n}$ & 10 & $109 A 7+21 S 9$ & $125.97 \pm 2.43^{\circ}$ \\
\hline \multirow{4}{*}{$\underset{(08 / m i)}{\operatorname{nxa}}$} & & Conird & $25 \mathrm{mM}$ & $50 \mathrm{mM}$ \\
\hline & Ith & $0 D C A+0,12$ & $0 \omega 047 \pm 001$ & $00110=0002^{\circ}$ \\
\hline & 24h & 0.0044000 & $00060+0002$ & $00123+0001^{\circ}$ \\
\hline & $7 \mathbf{h}$ & $0.00 / \pm 0 \% \bar{Q}$ & $0002+0003$ & $00120 \div 0004^{\circ}$ \\
\hline
\end{tabular}

Figure 3: Effects of ethanol treatments in JEG3 cells HOG production. $\{\mathrm{A}\}$ Representative Western blot detecting IGF2. $\{B\}$ Columns show the mean $\pm \mathrm{SD}$ of $25 \mathrm{mM}$ and $50 \mathrm{mM}$ groups normalized against the control group represented as a discontinuous line $\{100 \mathrm{AU}\}$. Results are expressed as arbitrary units $\{A U\}$. $\{C\}$ columns show the mean \pm SD HOG content in JEG3 cells culture medium from the three groups measured by ELISA. Results are expressed as pg/cell. \{D\} Western blot and ELISA results for each group. ${ }^{*} p<0.005$ vs. control.

described whether there was a dose- or time-dependent correlation. Our data proved that the increased levels of IGF2 in our preliminary in vitro model were dependent on the dose of ethanol received. This fact is relevant because it shows correspondence between dose and response, behaviour which is essential for being candidate molecules to biomarkers of damage. Although, as seen in the literature review, IGF2 was already postulated to this use, our study refills a gap of evidence about cellular behaviour under controlled conditions of alcohol exposure.

The second observation about placental hormone production was the detection of a high expression of hCG in cell lysates by Western blot, in agreement with subsequent ELISA results, in a significant dose-dependent manner. hCG is a glycoprotein with similar biological activity to luteinizing hormone. hCG has multiple biological functions, the best known being the corpus luteum stimulation to maintain progesterone production [32]. A previous in vitro report showed an increase in hCG production in trophoblast cells exposed to ethanol $[17,22]$. However, they used an experimental design that exposed cells to a daily peak concentration of $0-150 \mathrm{mM}$ of ethanol. Using these amounts, they observed a peak hCG level at $65 \mathrm{mM}$. This dose of ethanol is far for being similar to the standard human levels of ethanol [33]. In our study, we extended these observations and analyzed whether there was a constant release pattern according to the exposure time and the ethanol dosage. Our results proved that the ethanol dosage is significant and that hCG released by trophoblast cells increased in an amount-depending manner.

Finally, we observed a significant decrease in the number of viable cells related to ethanol exposure times. This was observed in other in vitro culture cell types exposed to ethanol $[29,34,35]$. Therefore, our study showed that alcohol causes cell damage and thus, interferences in hormone release levels, could be used as primary targets for the research of possible biomarkers of damage.

Our study showed the different behavior of two molecules depending on the concentration of ethanol they were exposed to. This was proved on a specific trophoblast cell line and with a coherent design, comparing groups exposed to standard concentrations of ethanol. These results should be considered preliminary and future studies will be needed to validate these findings in clinical human placental samples. Finally, it will be necessary to check these potential biomarkers in a cohort of pregnant women with alcohol use, primarily due to physiological variability in hormones.

In conclusion, the present results showed that ethanol induced

(A)

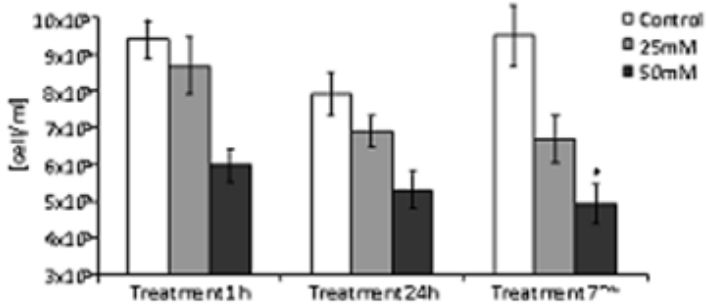

(B)

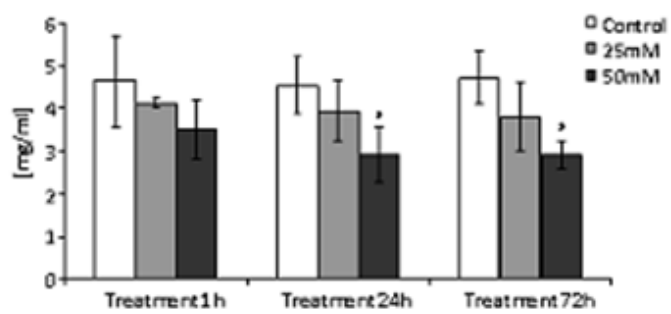

(c)

\begin{tabular}{|c|c|c|c|c|}
\hline \multicolumn{5}{|c|}{ Cdl vibility } \\
\hline \multirow{4}{*}{$\begin{array}{c}\text { Visle anunt } \\
\text { [all/mil] }\end{array}$} & & Contrel & $25 \mathrm{~mm}$ & somph \\
\hline & 1h & $8 m 50252567$ & 01750047527 & SAR50:4m73 \\
\hline & $24 \pi$ & $741250+518925$ & $631750+41710$ & $400000+4780$ \\
\hline & $7 \mathrm{~h}$ & $900000 \pm 11029$ & $620000+84336$ & $42500 \pm 5231 x^{\circ}$ \\
\hline \multicolumn{5}{|c|}{ Potainlewds } \\
\hline \multirow{4}{*}{$\begin{array}{c}\text { Conamitration } \\
\text { 'me/ml] }\end{array}$} & & Centrel & $25 \mathrm{~mm}$ & SDmth \\
\hline & $2 \mathrm{~h}$ & $4.04 \times 1.05$ & $412 \pm 0.13$ & 3530.68 \\
\hline & $24 h$ & $4.54 \div 0.66$ & $354=0.72$ & $3.94 \pm 072^{\circ}$ \\
\hline & $72 \mathrm{~h}$ & $4.71 \pm 0.61$ & $3.72 \pm 0.1$ & $2.92 \pm 0.31^{\circ}$ \\
\hline
\end{tabular}

Figure 4: Viable cell count after treatment and total protein quantification in JEG3 cells exposed to ethanol. $\{A\}$ Cell number mean $\pm S D\}$ assessed by trypan blue exclusion method in the three groups. Results are expressed as arbitrary units cell $/ \mathrm{ml}$. $\{B\}$ Total protein $\{$ mean \pm SD $\}$ measured with DC protein Assay in the three groups. Results are expressed as $\mathrm{mg} / \mathrm{ml}$. $\{\mathrm{C}\}$ viable count and protein quantification results. " $p<0.005$ vs. control. 
Citation: Clave S, Joya X, Salat-Batlle J, Martinez SE, Garcia-Algar O, et al. (2014) Effects of Ethanol Sustained Exposure on Human Trophoblast Cell Hormonal Production. J Steroids Horm Sci 5: 121. doi:10.4172/2157-7536.1000121

changes in the hormonal secretory JEG3 trophoblast function. In our study, we observed a significant increase in IGF2 and hCG production, which could be considered in future studies as preliminarily surrogate biomarkers of damage induced by prenatal ethanol exposure.

\section{Acknowledgements}

The present study was supported by a grant of the Fondo de Investigaciones Sanitarias (FIS) (PI10/02593) and Red de Salud Materno-Infantil y del Desarrollo (SAMID) (RD12/0026/0003) from the Instituto Carlos III (Spain), by intramural funding of the Neuroscience Program at Institut Hospital del Mar d'Investigacions Mèdiques (IMIM) and partially supported by Agència de Gestió d'Ajuts Universitaris i de Recerca (AGAUR) (2009SGR1388) from the Generalitat de Catalunya (Spain).

The authors wish to thank Asunción Romero Molina, DVM, PhD Physiopathology and Pain Management Research Group, Institut Hospital del Mar d'Investigacions Mèdiques (IMIM); for careful reading of the manuscript and assistance.

\section{References}

1. Benassi-Evans B, Fenech M (2011) Chronic alcohol exposure induces genome damage measured using the cytokinesis-block micronucleus cytome assay and aneuploidy in human B lymphoblastoid cell lines. Mutagenesis 26: 421-429.

2. Clarren SK, Smith DW (1978) The fetal alcohol syndrome. N Engl J Med 298: 1063-1067.

3. Jones KL, Smith DW (1973) Recognition of the fetal alcohol syndrome in early infancy. Lancet 302: 999-1001.

4. Moore ES, Ward RE, Wetherill LF, Rogers JL, Autti-Rämö I, et al. (2007) Unique facial features distinguish fetal alcohol syndrome patients and controls in diverse ethnic populations. Alcohol Clin Exp Res 31: 1707-1713.

5. Rostand A, Kaminski M, Lelong N, Dehaene P, Delestret I, et al. (1990) Alcohol use in pregnancy, craniofacial features, and fetal growth. J Epidemiol Community Health 44: 302-306

6. Gemma S, Vichi S, Testai E (2006) Individual susceptibility and alcohol effects:biochemical and genetic aspects. Ann Ist Super Sanita 42: 8-16.

7. Sampson PD, Streissguth AP, Bookstein FL, Little RE, Clarren SK, et al (1997) Incidence of fetal alcohol syndrome and prevalence of alcohol-related neurodevelopmental disorder. Teratology 56: 317-326.

8. May PA, Gossage JP, Marais AS, Hendricks LS, Snell CL, et al. (2008) Materna risk factors for fetal alcohol syndrome and partial fetal alcohol syndrome in South Africa: a third study. Alcohol Clin Exp Res 32: 738-753.

9. Bearer CF (2001) Markers to detect drinking during pregnancy. Alcohol Res Health 25: 210-218.

10. Joya X, Friguls B, Ortigosa S, Papaseit E, Martínez SE, et al. (2012) Determination of maternal-fetal biomarkers of prenatal exposure to ethanol: a review. J Pharm Biomed Anal 69: 209-222.

11. Datta S, Turner D, Singh R, Ruest LB, Pierce WM Jr, et al. (2008) Fetal alcoho syndrome (FAS) in C57BL/6 mice detected through proteomics screening of the amniotic fluid. Birth Defects Res A Clin Mol Teratol 82: 177-186.

12. Yu HS, Oyama T, Matsuda T, Isse T, Yamaguchi T, et al. (2012) The effect of ethanol on the formation of N2-ethylidene-dG adducts in mice: implications for alcohol-related carcinogenicity of the oral cavity and esophagus. Biomarkers 17: $269-274$

13. Benirschke K, Kaufmann P (2000) Pathology of the human placenta. (4th edn.), Springer, New York, USA

14. Burd L, Roberts D, Olson M, Odendaal H (2007) Ethanol and the placenta: A review. J Matern Fetal Neonatal Med 20: 361-375.

15. Burleigh DW, Kendziorski CM, Choi YJ, Grindle KM, Grendell RL, et al. (2007) Microarray analysis of BeWo and JEG3 trophoblast cell lines: identification of differentially expressed transcripts. Placenta 28: 383-389.
16. Kurman RJ, Main CS, Chen HC (1984) Intermediate trophoblast: a distinctive form of trophoblast with specific morphological, biochemical and functional features. Placenta 5: 349-369.

17. Karl PI, Fisher SE (1993) Ethanol alters hormone production in cultured human placental trophoblasts. Alcohol Clin Exp Res 17: 816-821.

18. Aros S, Mills JL, Iñiguez G, Avila A, Conley MR, et al. (2011) Effects of prenatal ethanol exposure on postnatal growth and the insulin-like growth factor axis. Horm Res Paediatr 75: 166-173.

19. Halmesmäki E, Autti I, Granström ML, Heikinheimo M, Raivio KO, et al. (1987) Prediction of fetal alcohol syndrome by maternal alpha fetoprotein, human placental lactogen and pregnancy specific beta 1-glycoprotein. Alcohol Alcohol Suppl 1: 473-476.

20. Clark PA, Xie J, Li S, Zhang X, Coonrod S, et al. (2013) Matrix metalloproteinase 9 is a distal-less 3 target-gene in placental trophoblast cells. Am J Physiol Cell Physiol 305: C173-181.

21. Ding $Y$, Ma L, Wang $X Z$, Zhang J, Zhao GZ, et al. (2011) In vitro study on hepatitis B virus infecting human choriocarcinoma JEG3 cells and its mechanism. Intervirology 54: 276-281.

22. Karl PI, Divald A, Diehl AM, Fisher SE (1998) Altered cyclic AMP-dependent human chorionic gonadotropin production in cultured human placenta trophoblasts exposed to ethanol. Biochem Pharmacol 55: 45-51.

23. Eckardt MJ, File SE, Gessa GL, Grant KA, Guerri C, et al. (1998) Effects of moderate alcohol consumption on the central nervous system. Alcohol Clin Exp Res 22: 998-1040.

24. Jones AW, Sternebring B (1992) Kinetics of ethanol and methanol in alcoholics during detoxification. Alcohol Alcohol 27: 641-647.

25. Eysseric H, Gonthier B, Soubeyran A, Bessard G, Saxod R, et al. (1997) There is not simple method to maintain a constant ethanol concentration in longterm cell culture: keys to a solution applied to the survey of astrocytic ethanol absorption. Alcohol 14: 111-115.

26. Signorini-Allibe N, Gonthier B, Lamarche F, Eysseric H, Barret L (2005) Chronic consumption of ethanol leads to substantial cell damage in cultured rat astrocytes in conditions promoting acetaldehyde accumulation. Alcohol Alcohol 40: $163-171$.

27. Ramadoss J, Jobe SO, Magness RR (2011) Alcohol and maternal uterine vascular adaptations during pregnancy-part I: effects of chronic in vitro bingelike alcohol on uterine endothelial nitric oxide system and function. Alcohol Clin Exp Res 35: 1686-1693.

28. Eysseric H, Gonthier B, Soubeyran A, Richard MJ, Daveloose D, et al. (2000) Effects of chronic ethanol exposure on acetaldehyde and free radical production by astrocytes in culture. Alcohol 21: 117-125.

29. Lamarche F, Gonthier B, Signorini N, Eysseric H, Barret L (2003) Acute exposure of cultured neurones to ethanol results in reversible DNA singlestrand breaks; whereas chronic exposure causes loss of cell viability. Alcohol Alcohol 38: 550-558.

30. Giovannone B, Scaldaferri ML, Federici M, Porzio O, Lauro D, et al. (2000) Insulin receptor substrate (IRS) transduction system: distinct and overlapping signaling potential. Diabetes Metab Res Rev 16: 434-441.

31. Gundogan F, Elwood G, Longato L, Tong M, Feijoo A, et al. (2008) Impaired placentation in fetal alcohol syndrome. Placenta 29: 148-157.

32. Rahman NA, Rao CV (2009) Recent progress in luteinizing hormone/human chorionic gonadotrophin hormone research. Mol Hum Reprod 15: 703-711.

33. Urso T, Gavaler JS, Van Thiel DH (1981) Blood ethanol levels in sober alcoho users seen in an emergency room. Life Sci 28: 1053-1056.

34. Chan WH, Chang YJ (2006) Dosage effects of resveratrol on ethanol-induced cell death in the human K562 cell line. Toxicol Lett 161: 1-9.

35. Jacobs JS, Miller MW (2001) Proliferation and death of cultured fetal neocortical neurons: effects of ethanol on the dynamics of cell growth. J Neurocytol 30 391-401. 